\section{Temperature Impacts Cactus and Succulent Development Rate}

\author{
John Erwin ${ }^{1,4}$, Ken Altman ${ }^{2}$, and Fran Esqueda ${ }^{3}$
}

AdDitional InDEX words. leaf unfolding, tubercle unfolding, Echeveria, Aloe, Crassula

Summary. One cactus and 17 succulent species/cultivars were grown at 10, 16, 22, or $28{ }^{\circ} \mathrm{C}$ (plant temperature) for 10 or 15 weeks. The change in leaf/tubercle number at each temperature (after 10 or 15 weeks) was determined, and leaf/ tubercle-unfolding rate was calculated. 'Jade Necklace' kebab bush (Crassula rupestris ssp. marnieriana), 'Lola' echeveria (Echeveria), 'Green Ice' gasteraloe (Gasteraloe), and lithops (Lithops species) leaf-unfolding rate per day was unaffected by temperature. Leaf-unfolding rate per day increased as temperature increased from 10 to $16{ }^{\circ} \mathrm{C}$ on 'Firebird' aloe (Aloe), 'Key Lime Pie' adromischus (Adromischus cristatus), prostate rainbow bush (Portulacaria afra variegata), burro's tail (Sedum burrito), and 'Sir William Lawrence' houseleek (Sempervivum calcareum). Leaf-unfolding rate per day increased as temperature increased from 10 to $22{ }^{\circ} \mathrm{C}$ on mescal agave (Agave parryi truncata), 'Firebird' aloe, Sunrise anacampseros (Anacampseros telephiastrum variegata), ponytail palm (Beaucarnea recurvata), subsessilis echeveria (Echeveria subsessilis), zebra plant (Haworthia fasciata), prostrate rainbow bush, burro's tail and 'Sir William Lawrence' houseleek. Increasing temperature from 22 to $28{ }^{\circ} \mathrm{C}$ decreased 'Kiwi' tree houseleek (Aeonium percarneum) leaf-unfolding rate per day, increased 'Firebird' aloe and tiger tooth aloe (Aloe juvenna) leaf-unfolding rate, and resulted in shoot tip death on burro's tail, and plant death of 'Sir William Lawrence' houseleek and 'Silver Dollar' jade (Crassula arborescens). The cactus, 'Arizona Snowcap' mammillaria (Mammillaria gracilis fragilis), tubercle-unfolding rate per day increased as temperature increased from 16 to $28{ }^{\circ} \mathrm{C}$. Taken together, temperature $\left(10\right.$ to $\left.28{ }^{\circ} \mathrm{C}\right)$ effects on development rate were species specific and related to the indigenous environment of a species.

I nterest in cacti and succulents as ornamental-potted and landscape plants has increased recently. Cacti and succulents can have ornamental foliage, or spines, unique forms and occasionally showy flowers. Cacti and succulents originate from a variety of climates (temperate, tropical, desert) but are similar in that each environment has periodic or prolonged drought (Anderson, 2001; Bailey, 1976).

Temperature effects on development rate are often quantified by

\footnotetext{
We thank Rene O'Connell (Altman Plants, Inc.) for her help in selection of plant material. We also acknowledge the University of Minnesota Agriculture Experiment Station, the USDA-ARS Floriculture and Nursery Research Initiative, the Society of Allied Florists, and the Floriculture Research Alliance for their financial support of this project.

${ }^{1}$ Department of Horticultural Science, 1970 Folwell Avenue, University of Minnesota, St. Paul, MN 55108

${ }^{2}$ President, Altman Plants, Inc., 3742 Blue Bird Canyon Road, Vista, CA 92084

${ }^{3}$ Cactus and Succulent Production Manager, Altman Plants, Inc., 3742 Blue Bird Canyon Road, Vista, CA 92084

${ }^{4}$ Corresponding author. E-mail: erwin001@umn.edu. doi: 10.21273/HORTTECH03515-16
}

assessing the impact of temperature on leaf unfolding over time. In general, leaf-unfolding rate per day (development rate) increases as average daily temperature increases within a limited temperature range (Roberts and Summerfield, 1987; Vaid and Runkle, 2013). There is little or no information on how temperature affects development rate of many commercially grown cacti and succulents. Succulents and cacti differ in indigenous habitat, which differ in temperature, and how temperature impacts development rate of each species may differ. Understanding how temperature affects cacti and succulent development rate would facilitate greenhouse environment management and help identify geographic locations to successfully produce and schedule each crop. The objective of research summarized here was to determine temperature effects (10 to $28{ }^{\circ} \mathrm{C}$ ) on cacti and succulent development rate to determine appropriate greenhouse temperatures and/ or optimal geographic locations to produce these crops.

\section{Materials and methods}

Three hundred sixty plants of 17 two-year-old vegetatively propagated succulent plant types and one sexually propagated cactus species grown in three $1 / 2$-inch-diameter plastic pots in a soilless media were received from Altman Plants, Inc., Vista, CA [20 plants of each species/cultivar (Table 1)]. Plants were unpacked and acclimatized in a greenhouse for at least 2 weeks $\left[22 \pm 1{ }^{\circ} \mathrm{C}\right.$ day $/ 18 \pm 1{ }^{\circ} \mathrm{C}$ night temperature; natural photoperiod $(10 \mathrm{~h})$; daily light integral $(\mathrm{DLI})=$ $\left.4.4 \mathrm{~mol} \cdot \mathrm{m}^{-2} \cdot \mathrm{d}^{-1}\right]$. Two hundred eighty-eight plants were selected for uniformity based on leaf number, plant height, and/or branch number (16 of each species/cultivar), and were then further divided into four groups of 18 plants each (one of each species per group). Each group was moved into one of four environmental growth chambers (over time) where air temperatures were managed in each to achieve a $10,16,22$, or $28{ }^{\circ} \mathrm{C}$ plant temperature (mean of three different infrared thermometer brands across species). The uppermost "unfolded" $\left(\geq 45^{\circ}\right.$ from the main stem axis) leaf (succulents) or tubercle (cactus) on each plant was marked using an indelible ink marker when plants were placed in chambers based on the angle of that leaf/tubercle to the main stem. Chamber irradiance and photoperiod were 300 $\mu \mathrm{mol} \cdot \mathrm{m}^{-2} \cdot \mathrm{s}^{-1}[75 \%$ wattage from fluorescent lamps and $25 \%$ from incandescent lamps (DLI $=12.96 \mathrm{~mol}$. $\left.\left.\mathrm{m}^{-2} \cdot \mathrm{d}^{-1}\right)\right]$ and $12 \mathrm{~h}$, respectively, and chamber humidity was set to $40 \%$. Plants were watered as needed (media at the bottom of the pot never dried) and were fertilized once weekly with a solution containing $250 \mathrm{ppm}$ nitrogen from a $15 \mathrm{~N}-2.2 \mathrm{P}-12.5 \mathrm{~K}$

\begin{tabular}{llll}
\hline $\begin{array}{l}\text { Units } \\
\text { To convert U.S. to SI, } \\
\text { multiply by }\end{array}$ & U.S. unit & SI unit & $\begin{array}{l}\text { To convert SI to U.S., } \\
\text { multiply by }\end{array}$ \\
\hline 2.54 & inch $(\mathrm{es})$ & $\mathrm{cm}$ & 0.3937 \\
1 & $\mathrm{ppm}$ & $\mathrm{mL} \cdot \mathrm{m}^{-3}$ & 1 \\
$\left({ }^{\circ} \mathrm{F}-32\right) \div 1.8$ & ${ }^{\circ} \mathrm{F}$ & ${ }^{\circ} \mathrm{C}$ & $\left({ }^{\circ} \mathrm{C} \times 1.8\right)+32$
\end{tabular}


Table 1. Succulent and cactus plant material evaluated for variation in temperature effects [ 10 to $25^{\circ} \mathrm{C}\left(50.0\right.$ to $\left.77.0{ }^{\circ} \mathrm{F}\right)$ ] on leaf/tubercle-unfolding rate per day and the indigenous habitat that each plant is from.

\begin{tabular}{ll}
\hline Plant & \multicolumn{1}{c}{ Indigenous habitat $^{\text {z }}$} \\
\hline 'Kiwi' tree houseleek & Canary Islands \\
Mescal agave & Southwest United States and Mexico \\
'Firebird' aloe & Southern Africa \\
Tiger tooth aloe & Southern Africa \\
Sunrise anacampseros & South Africa \\
'Key Lime Pie' adromischus & South Africa (mountains) \\
Ponytail palm & Texas and Mexico \\
'Silver Dollar' jade & Madagascar \\
'Jade Necklace' kebab bush & South Africa/Madagascar \\
'Lola' echeveria & Texas to Argentina \\
Subsessilis echeveria & Texas to Argentina \\
'Green Ice' gasteraloe & South Africa \\
Zebra plant & South Africa \\
Lithops & Western South Africa/Namibia \\
'Arizona Snowcap' mammillaria & Central Mexico \\
Prostrate rainbow bush & South Africa \\
Burro's tail & Eastern Mexico (mountains) \\
'Sir William Lawrence' houseleek & Europe, Morocco/west Asia \\
\hline
\end{tabular}

${ }^{\mathrm{z} B a i l e y ~(1976), ~ A n d e r s o n ~(2001) . ~}$

fertilizer (Excel 15-5-15 Cal-Mag; Everris, Marysville, $\mathrm{OH})$. Plants were not leached to insure media fertility was similar between temperature treatments.

Nine succulent species/cultivars with more rapid leaf unfolding were removed from chambers after 10 weeks (greater than three leaves unfolded after 10 weeks). A second group of nine species/cultivars with a slower leaf/tubercle-unfolding rate (less than three leaves/tubercles unfolded after 10 weeks) was removed after 15 weeks. "Unfolded" leaf/tubercle number above the mark when plants were moved in was counted when plants were removed from chambers. The leaf/tubercle-unfolding rate per day for each plant was calculated by dividing the number of new leaves/tubercles unfolded in chambers by time in chambers $(70$ or $95 \mathrm{~d})$. The experiment was organized in a completely randomized statistical design in a factorial arrangement with temperature and species/cultivar as the main factors. The experiment was replicated four times over time (one plant/replicate). Analysis of variance was conducted using SPSS [version 24; IBM Corp., Armonk, NY (Table 2)]. Regression analysis across temperatures (within a species) was also conducted (Table 2). The Tukey's honestly significant difference test at $P \leq 0.05$ was employed for mean separation.

\section{Results}

How temperature affected development rate differed among species and cultivars (Table 2). Temperature (10 to $28^{\circ} \mathrm{C}$ ) did not affect development rate of 'Jade Necklace' kebab bush, 'Lola' echeveria, 'Green Ice' gasteraloe, and lithops (Table 2). In contrast, leaf-unfolding rate per day increased as temperature increased from 10 to $16^{\circ} \mathrm{C}$ on 'Firebird' aloe, 'Key Lime Pie' adromischus, prostrate rainbow bush, burro's tail, and 'Sir William Lawrence' houseleek (Table 2). Leaf-unfolding rate per day increased when temperature increased from 10 to $22{ }^{\circ} \mathrm{C}$ on mescal agave, 'Firebird' aloe, Sunrise anacampseros, ponytail palm, subsessilis echeveria, zebra plant, prostrate rainbow bush, burro's tail, and 'Sir William Lawrence' houseleek (Table 2). 'Arizona Snowcap' mammillaria tubercle-unfolding rate increased as temperature increased from 16 to $28{ }^{\circ} \mathrm{C}$ (Table 2).

Increasing temperature from 22 to $28^{\circ} \mathrm{C}$ decreased 'Kiwi' tree houseleek leaf-unfolding rate, but 'Firebird' aloe and tiger tooth aloe leafunfolding rate per day increased (Table 2). Although not significant, zebra plant and prostrate rainbow bush leafunfolding rate per day increased when temperature increased from 22 to $28^{\circ} \mathrm{C}$ (Table 2). The apical meristem of burro's tail died, and the entire plant of 'Sir William Lawrence' houseleek and 'Silver Dollar' jade died when temperature increased from 22 to $28{ }^{\circ} \mathrm{C}$ (Table 2).

\section{Discussion}

Intermediate temperature (similar to here) effects on development rate of some succulents and tropical cacti have been studied. Kalanchoe [Kalanchoe blossfeldiana (indigenous to Madagascar; Bailey, 1976)] time to flower decreased $19 \mathrm{~d}$ when temperature increased from 18 to $24^{\circ} \mathrm{C}$, but decreased only $2 \mathrm{~d}$ more when temperature was increased further from 24 to $26^{\circ} \mathrm{C}$ (Carvalho et al., 2006). Thanksgiving cactus [Schlumbergera truncata (indigenous to Brazil; Bailey 1976)] days from flower induction to anthesis decreased from 100 to $52 \mathrm{~d}$ when average daily temperature increased from 12 to $20{ }^{\circ} \mathrm{C}$ and was unchanged when average daily temperature was further increased from 20 to $24{ }^{\circ} \mathrm{C}$ (Erwin et al., 1990). Maximum (64 to $71{ }^{\circ} \mathrm{C}$ ) or minimum temperature $\left(-22\right.$ to $\left.-5{ }^{\circ} \mathrm{C}\right)$ tolerance of desert cacti has been studied; however, there is little work on intermediate temperature effects on desert cacti development rate [as 'Arizona Snowcap' mammillaria here (Nobel and Bobich, 2002; Nobel and De la Barrera, 2003)].

There was considerable diversity in temperature effects on development rate of the cactus and succulents species/ cultivars studied here (Table 2 ). In some cases, we could identify temperatures with the fastest leaf/tubercle-unfolding rate per day. For instance, since 'Kiwi' tree houseleek and 'Key Lime Pie' adromischus development rate increased as temperature increased from 10 to $22^{\circ} \mathrm{C}$ and then decreased when temperature was further increased from 22 to $28^{\circ} \mathrm{C}$, we could elucidate that the highest leaf/ tubercle-unfolding rate per day was at, or near, $22{ }^{\circ} \mathrm{C}$ (Table 2). Also, the temperature with the highest leaf/ tubercle-unfolding rate for burro's tail, 'Sir William Lawrence' houseleek and 'Silver Dollar' jade development rate was $<28^{\circ} \mathrm{C}$, as the apical meristem or the entire plant died when plants were grown at $28{ }^{\circ} \mathrm{C}$ (Table 2$)$. Still other species/cultivars exhibited increased development rate when temperatures increased from 22 to $28^{\circ} \mathrm{C}$ indicating that the temperature with 
Table 2. Effect of plant temperature on leaves/tubercle unfolding per day and days to unfold three leaves/tubercles (three leaves divided by the leaf/tubercle-unfolding rate per day) of 17 succulent species/cultivars and one cactus species. Leaf and tubercle-unfolding rates were calculated after 10 (two decimals) or 15 weeks (three decimals). Regression analysis was conducted and the correlation between temperature and leaf-unfolding rate per day $\left(r^{2}\right)$ was determined and the statistical significance of linear $(\mathrm{L})$ and quadratic $(\mathrm{Q})$ regression terms are reported below. The temperature range where the "most rapid leaf/tubercle unfolding" was determined was based on that temperature with the highest leaf/tubercle-unfolding rate per day and determining what mean leaf/tubercle-unfolding rates per day were different or not using Tukey's honestly significant difference test (HSD).

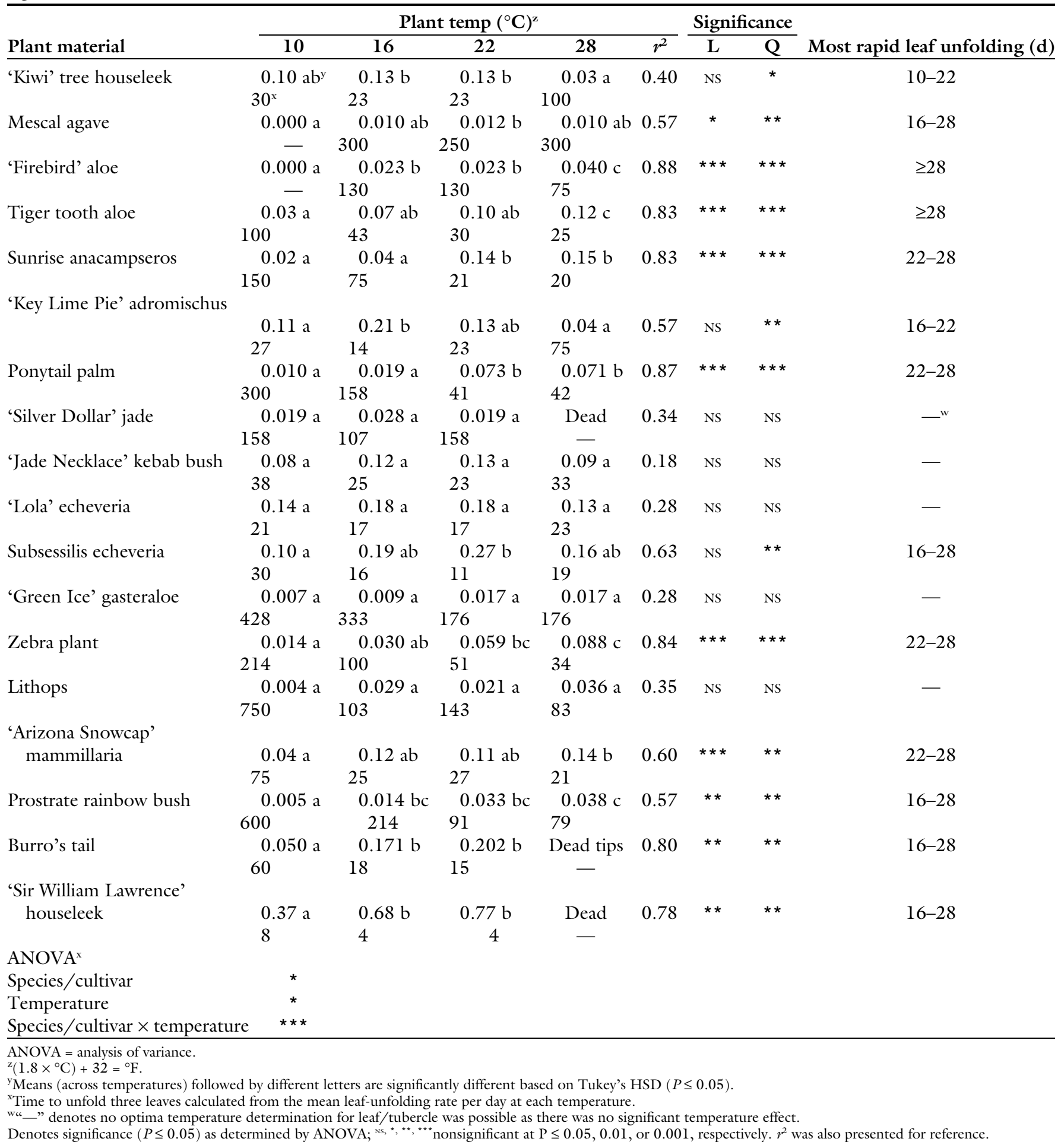

the highest leaf/tubercle-unfolding rate per day of these species/cultivars was $\geq 28^{\circ} \mathrm{C}$ (Table 2 ).
Species where development rate slowed when temperature increased from 22 to $28^{\circ} \mathrm{C}$ are indigenous to islands, mountains, or western Europe where more moderate temperatures may occur more than in tropical or 
desert climates (Table 1). Kalanchoe reportedly has an optimal temperature at or near $24-26^{\circ} \mathrm{C}$ (Carvalho et al., 2006); 'Silver Dollar' jade here (similar indigenous location as kalanchoe) had a similar optimal temperature (Table 2). In contrast, species with optimal development rate temperatures $\geq 28{ }^{\circ} \mathrm{C}$ here ('Firebird' aloe, tiger tooth aloe, zebra plant, prostrate rainbow bush, and 'Arizona Snowcap' mammillaria) are indigenous to interior regions, lowlands, or deserts of South Africa, or central Mexico with warmer temperatures (Table 1). Future work on species from warm regions should include temperatures $>28{ }^{\circ} \mathrm{C}$ to insure identification of optimal development rate temperatures.

We suspect burro's tail, Sir William Lawrence houseleek, and 'Silver Dollar' jade tip or plant death observed here was related to warm night temperatures, as these plants are routinely exposed to day temperatures $\geq 28{ }^{\circ} \mathrm{C}$ in commercial production and the landscape and plants do not die (personal observation). High night temperatures, or night temperatures similar to day temperatures, could limit carbon dioxide $\left(\mathrm{CO}_{2}\right)$ uptake and result in carbohydrate limitation of growth, as $\mathrm{CO}_{2}$ is taken up during the night on plants that exhibit crassulacean acid metabolism (CAM) as many cacti and succulents do. Prickly pear (Opuntia ficus-indica) maximum $\mathrm{CO}_{2}$ uptake occurred at a $15{ }^{\circ} \mathrm{C}$ night temperature (Nobel and Bobich, 2002; Nobel and Hartsock, 1984). In contrast, the epiphytic cacti night blooming cereus (Hylocereus undatus) had an optimal night temperature for $\mathrm{CO}_{2}$ uptake of $25{ }^{\circ} \mathrm{C}$
(Raveh et al., 1995). Whether plants studied here photosynthesize exclusively via the CAM pathway is not known; however, future work should focus on night temperature limitation of photosynthesis as such inhibition may have occurred on other species here that did not exhibit shoot tip or plant death. High night temperatures may also limit growth of some species/cultivars in the landscape in warmer climates or in buildings without expressing obvious symptoms.

Research results reported here provide some insight and guidance on how cactus and succulent production time may be impacted when temperature is changed between 10 and $28{ }^{\circ} \mathrm{C}$. For instance, calculated production time (three leaves divided by leaf-unfolding rate per day) to unfold three leaves at $22{ }^{\circ} \mathrm{C}$ was $130 \mathrm{~d}$ on 'Firebird' aloe, but was $75 \mathrm{~d}$ when plants were grown at $28{ }^{\circ} \mathrm{C}$ [55 d less time (Table 2)]. In contrast, 'Key Lime Pie' adromischus unfolded three leaves after $23 \mathrm{~d}$ when grown at $22{ }^{\circ} \mathrm{C}$, but took $75 \mathrm{~d}$ to unfold three leaves when grown at $28^{\circ} \mathrm{C}$ [53 d longer (Table 2)]. These data suggest that species/cultivars should be grouped by temperature development rate responses to insure greenhouse temperature management decisions or selection of outdoor production locations do not inadvertently increase production time.

\section{Literature cited}

Anderson, E.F. 2001. The cactus family. Timber Press, Portland, OR.
Bailey, L.H. 1976. Hortus third. Cornell University, Ithaca, NY.

Carvalho, S.M.P., S.E. Wuillai, and E.P. Huevelink. 2006. Combined effects of light and temperature on product quality of Kalanchoe blossfeldiana. Acta Hort. 711:121-126.

Erwin, J.E., R.D. Heins, R.D. Berghage, and B. Kovanda. 1990. Temperature effects on Schlumbergera truncata 'Madisto' flower initiation. Acta Hort. 272:97101.

Nobel, P.S. and E.G. Bobich. 2002. Environmental biology, p. 57-74. In: P.S. Nobel (ed.). Cacti biology and uses. Univ. California Press, Berkeley/Los Angeles, CA.

Nobel, P.S. and E. De la Barrera. 2003. Tolerances and acclimation to low and high temperature for cladodes, fruits and roots of a widely cultivated cactus, Opuntia ficus-indica. New Phytol. 157:271-279.

Nobel, P.S. and T.L. Hartsock. 1984. Physiological responses of Opuntia ficusindica to growth temperature. Physiol. Plant. 60:98-105.

Raveh, E., M. Gersani, and P.S. Nobel. 1995. $\mathrm{CO}_{2}$ uptake and fluorescence responses for shade-tolerant cactus Hylocereus undatus under current and doubled $\mathrm{CO}_{2}$ concentrations. Physiol. Plant. 93:505-511.

Roberts, E.H. and R.J. Summerfield. 1987. Measurement and prediction of flowering in annual crops, p. 17-50. In: J. G. Atherton (ed.). Manipulation of flowering. Butterworth-Heinemann, Oxford, UK.

Vaid, T.M. and E.S. Runkle. 2013. Developing flowering rate models in response to mean temperature for common annual ornamental crops. Sci. Hort. 161:15-23. 